Land remediation, event spaces and the pursuit of Olympic legacy

John R. Gold and Margaret M. Gold

Running title: Land remediation and legacy

Authors: John Robert Gold

Margaret Mary Gold

Addresses:

Professor John R. Gold, Department of Social Sciences, Oxford Brookes University, Gipsy Lane, Headington, Oxford, OX3 OBP, United Kingdom

E-mail: jrgold@brookes.ac.uk

Mrs Margaret M. Gold, Senior Lecturer in Creative Industries, Guildhall School of Business and Law, London Metropolitan University, 166-220 Holloway Road, London, N7 8DB, United Kingdom

E-mail:m.gold@londonmet.ac.uk

This is the final and accepted manuscript version of a paper to be published in Geography Compass, volume 14 (2020). For correct citation, please see published version. 


\section{Land remediation, Olympic event spaces and the pursuit of legacy}

\section{Abstract}

This paper explores the links between remediating land for Olympic event spaces and the pursuit of legacy. In particular, it considers ways in which redevelopment of the sizeable spaces prepared for staging the event take their place in broader strategies intended to bring long-term benefits to the host city and society in order to compensate for the costs and inconvenience originally incurred in hosting the Games. There are six main sections. The first analyses the diverse nature of brownfield land and highlights salient characteristics of its remediation for use in urban regeneration. The second supplies background to Olympic legacy and indicates the importance of the changing climate of ideas in understanding the formulation of legacy over the past two decades. The third section documents the role of remediation as an option employed recently by Games' organisers when needing to find spaces of suitable size to stage the Olympics, noting how choosing remediation $a b$ initio involves commitment to legacy. The fourth and fifth parts analyse approaches to implementing remediation, with respect to the key event spaces for two of the twenty-first century's Summer Games: Homebush Bay, which housed the Olympic Park for Sydney 2000; and the Lower Lea Valley, which served the same function for London 2012. The final section provides commentary on the wider narratives of transformation associated with deployment of remediated sites for Olympic event spaces and indicates the significance of the values that have underpinned those narratives.

Key Words: remediated land, Olympic legacy, masterplanning, placemaking, Sydney, London, narratives 


\section{Introduction}

The priorities, strategies and consequences of using megaevents as catalysts for 'driving urban change' (Essex and de Groot, 2017) have attracted a large and diverse literature (Roche, 2002; Gold and Gold, 2005; Hiller, 2006; Smith, 2012; Müller, 2015; Dickinson et al, 2016; Horne, 2017). Defined as festivals possessing the scale, impact and media visibility to attract global attention, megaevents are typically ambulatory rather than staged each time at a permanent location. This characteristic presents their hosts, normally the designated cities, with two important challenges. First, they require large-scale sites, preferably close to the heart of the city, in which to stage the event; a difficult task given that most host cities are already densely developed. Secondly, given that any specific megaevent is unlikely to be repeated in the same city within several generations, the spaces thus acquired and facilities provided will normally require post-event conversion. Ideally this will be accomplished in ways that compensate for the heavy initial costs of site preparation, avoid expensive 'white elephants' in the shape of architecturally spectacular but functionally limited venues (Mangan, 2008), and provide a lasting beneficial legacy for the host city and society.

Set against this background, this paper examines the experience of Sydney 2000 and London 2012, two twenty-first century Summer Olympic Games that employed substantial plots of remediated land for event spaces. In doing so, the aim is more to explore the conceptual and empirical relationships between remediation and legacy rather than to review their progress to date, for which other sources are available (Cashman, 2008, 2011; Evans, 2016; Cohen and Watt, 2017; Evans and Edizel, 2017; Freestone and Gunasekara, 2017). The opening part of this paper contextualizes the nature and characteristics of remediated land and highlights salient characteristics of its valorisation into productive space. The second discusses Olympic legacy - now the dominant lens for viewing postGames developments - and indicates the importance of recognising how much the changing climate of ideas has affected formulations of legacy. The third section identifies the use made of remediated land as an option to which Games' organizers have recently resorted when choosing event spaces. The next two sections turn to the case studies, with comparative discussion of their remediation histories and the subsequent stages of masterplanning. The conclusion provides commentary about the wider narratives evoked when considering the deployment of remediated sites as Olympic event spaces.

\section{Remediated Land}

The 'interwoven geographies of industrial disinvestment and environmental contamination' (Bjelland, 2004; also Bliek and Gauthier, 2007) have left a patchwork of marginalized, derelict and often polluted spaces in cities throughout the developed world. Frequently labelled 'brownfield land' - a term first used jocularly in the mid-1970s in contrast to 'greenfield land', but applied more seriously from 1992 onwards as a formal concept (Gemill, 2012, 4) - these spaces are defined with varying inclusivity (Alker et al, 2000). American parlance restricted 'brownfield' to refer to contaminated industrial sites, with the Environmental Protection Agency in 1997 defining the term as: 'Abandoned, idled, or underused industrial and commercial facilities where expansion or redevelopment is complicated by real or perceived environmental contamination' (Gemill, 2012, 4). By contrast, 
'brownfield' elsewhere could mean anything 'from polluted industrial landscapes to former factory buildings, including vacant or abandoned properties... usually found in older, declining sections of a city' (Loures and Vaz, 2018, 66); to which might be added run-down waterfronts and derelict canal basins (Brownill, 2013; Bäing and Wong, 2018), redundant military establishments (Bagaeen, 2006) and rural manifestations of economic restructuring and decay (Norris et al, 2014). Most such sites are somewhat diminutive. The General Accounting Office identified between 400,000 and 500,000 derelict or abandoned sites in the USA in 1996 (Ryan, 1998, 20), with 6500 such sites in New York City alone (Shutkin, $2001,64)$. In 2006, the Commission of the European Communities provided a comparable figure of 3.5 million sites for the European Union (Meuser, 2013, vii). More recently, Banzhaf et al. (2018) identified 783 brownfields in the city of Leipzig (Germany), over 80 per cent of which were less than one hectare in size.

Yet even for smaller sites where conversion costs may not on the surface appear forbidding, the case for remediating land is often complicated by, inter alia, fragmentation of available plots, complex landownership, contested liabilities, poorly-understood tax regimes and the declining property values encountered during periods of recession (McGrath, 2000; Adams et al, 2002; Dixon et al, 2013; Leger et al, 2016). Although detailed analyses of the priorities of planning policies for remediating land lie beyond the scope of this paper (see Nijkamp et al, 2002; Genske, 2003; Dixon, 2006; Dixon et al, 2007; Hayek et al, 2010; Schädler et al, 2011; Hou and Al-Tabbaa, 2014; De Sousa, 2017; Smith, 2017), generally three considerations can shift the balance of judgement in favour of its use. The first is the presence of noteworthy industrial heritage (e.g. Reeves, 2011; Campo, 2019). This encourages viewing even damaged landscapes as a palimpsest through which the past can be glimpsed (Hetherington et al, 2019) and can revalorize features that will then be incorporated creatively into the cultural rebirth of a city and region (Dorstewitz, 2014; Cenci, 2018). Secondly, remediation can acquire a powerful moral dimension by repairing the damage caused by past industrialism. For example, it can remove the stigma attached to environmental blight (Bond, 2001; Harnik and Donahue, 2011; Harnik et al, 2006), eliminate contamination (Tarr, 2002), remove hazards to health (Gilbert and Hall, 2014), address the needs of vulnerable communities (Scott et al, 2016), and promote environmental justice (Lee, 2015). Thirdly, remediation is closely linked to the rationale and outcomes of staging large-scale festivals; a theme given international visibility by recent examples in which substantial plots of land have been remediated as event spaces for the Olympic Games. As shown below, these would prove a particularly challenging category of brownfield land due to their size, degree of contamination and limited infrastructure; all of which would necessitate significant public investment before construction could begin but would depend on private-sector funds in order to achieve desired post-event conversion.

\section{Olympic Legacy}

At the outset, it is important to recognise that the recent rationale for deploying such land was filtered by nascent concerns with legacy. As such, current thinking was shaped by the report of an invited symposium held at Lausanne in 2002 under International Olympic Committee (IOC) auspices. When asked to define the meaning of legacy as a word that had featured increasingly in Olympic discourse between 1984 and 2000, the gathering defined it as an omnium gatherum of Games-related outcomes ranging from 'urban planning, city 
marketing...and tourist development' to 'production of ideas and cultural values, intercultural and non-exclusionary experiences...popular memory, education, archives, collective effort and voluntarism' (Moragas et al, 2003, 2). The IOC accepted the symposium's inclusive approach, as well as the idea that the Olympic movement should proactively promote locally beneficial outcomes from staging the Games. In 2003 the Olympic Charter was amended, adding a clause committing the $\mathrm{IOC}$ to take 'measures to promote a positive legacy from the Olympic Games to the host city and the host country' (IOC, 2003, 12).

From these beginnings, interest quickly spiralled. By 2008, legacy was already 'central to any research agenda deriving from the modern Olympics' (Gold and Gold, 2008, 313), with the next decade bringing studies of legacy outcomes that might be sport- or nonsport related, planned or unplanned, direct or indirect, intentional or unintentional, shortor long-term, local or global, selective or universal, low-cost or hugely expensive (Roult and Lefebvre, 2010, 2013; Chappelet, 2012; Leopkey and Parent, 2012; Holt and Ruta, 2015; Preuss, 2015; Tomlinson, 2016; Grix, 2017; Scheu and Preuss, 2017; Girginov, 2018). Yet it is also essential to stress that the relationship between notions of legacy and the prevailing climates of ideas. Initial conceptions of legacy developed against a background dominated by neoliberalist economic restructuring (Larner, 2003) and notions of urban entrepreneurialism (Hall and Hubbard, 1998). As such, thinking was strongly disposed towards the lasting positive benefits to be achieved from Olympic projects, with particular credence given to the so-called 'Barcelona model' (Monclús, 2003; Carné and Ivancic, 2008; Illas, 2012). The success of the 1992 Summer Games had come as the culmination of the city's longstanding policies of linking eye-catching infrastructural and urban design improvements to the attraction of large-scale projects; seemingly affirming what could be achieved in terms of urban redevelopment when underlying vision was linked to robust civic leadership.

The strength of the case for Olympic legacy, however, was quickly challenged by changing circumstances. The 2008 global financial crisis raised the spectre of retrenchment (Gold and Gold, 2009). Local residents and environmental groups that were unconvinced about the potential gains from hosting the Olympics opposed their cities' bids for the Games (Timms, 2012; Tomlinson, 2014). The popular and professional media shifted their stance from largely uncritical approval towards greater negativity, characteristically highlighting instances of poor planning, overambitious stadium design, heavy cost overruns, environmental damage, security and militarisation, corruption, and lack of accountability (e.g. Giulianotti, 2013; Karamichas, 2013; Raco, 2014; Pavoni, 2015; Talbot, 2019). These developments were not without precedent. For example, Denver had withdrawn as host city for the 1976 Winter Games after a public plebiscite and commentators had long expressed doubts about the universality of the Barcelona model of megaevent-led regeneration (e.g. Marshall, 2000, 317). Yet what were then isolated incidents and voices subsequently became routine elements in the discourse surrounding Olympic legacy. Indeed, over the last decade negative aspects of Olympic involvement have been emphasised as readily as positive (Gaffney, 2013) and nowhere more so than with respect to the costly and multifaceted outcomes linked to the Games' ambulatory modus operandi and the host city's need to prepare event spaces. 


\section{Event Spaces as Legacy}

Although hybrid mixes of concentrated and dispersed locational patterns have been employed when choosing event spaces (e.g. Pitts and Liao, 2009), broadly speaking four main options have been used (Table 1). Temporary solutions, the first category, bring together pragmatic strategies designed either to eradicate the Games' lasting physical traces or reduce their long-term legacy footprint. This is a historic strategy that retains contemporary relevance. Early Games such as Paris 1900 and St Louis 1904 relied entirely on ad hoc event spaces, with no investment in permanent facilities. The 1932 Olympics employed the Los Angeles Memorial Coliseum, opened in 1923, as its main stadium; a strategy retained for the 1984 and 2028 Games. Atlanta 1996 followed Los Angeles' lead in leasing facilities at local universities to provide the major indoor arenas, but developed its Olympic stadium with an eye to post-event conversion to a venue suitable for baseball. More recently, temporary solutions have attained enhanced status as a means of achieving greater value for money by avoiding commitment to permanent facilities for sporting activities where there is insufficient domestic demand as, for example, with London 2012's basketball arena. This policy also accords with current IOC policy. Most notably Agenda 2020, proclaimed as 'the strategic roadmap for the future of the Olympic movement', contained within its first recommendation the commitment to 'actively promote the maximum use of existing facilities and the use of temporary and demountable venues' (IOC, 2019).

***TABLE 1 about here***

Clearance, the second category, became particularly significant once Rome 1960 pioneered attaching substantial urban development to the Olympics (Essex and Chalkley, 1998, 2004; Gold and Gold, 2007, 2012). With clearance, however, came displacement. Precise figures are hard to obtain, since Games' developments may occur alongside overarching exercises in city planning, but some broad estimates are available. For instance, Centennial Park, a circulation space for Atlanta 1996 created by demolishing a rundown inner-city district, is reckoned to have displaced around 30,000 people; a figure dwarfed by the demolition of entire districts of vernacular housing (hanoks) that removed 720,000 people to accommodate the 1988 Seoul Summer Games and by the estimated 300,000 evicted by projects related to Beijing 2008 (COHRE, 2007). While the authorities in both Seoul and Beijing might argue that these developments bred a new texture back into their host cities and left tangible legacies of public parkland, sports venues and cultural quarters (Gold and Gold, 2017, 48-49), clearances on this scale are difficult now to contemplate even for authoritarian regimes given current Olympic agendas for sustainable legacy (see also below).

The third category, greenfield sites, covers both fringe and suburban locations. Using land at the urban periphery occurred frequently before the Second World War. The 1908 Olympics took place at the White City, a multipurpose stadium built on former agricultural land at Shepherd's Bush in west London; the Reichssportfeld for Berlin 1936 occupied a hilly and wooded area in the western part of the city. No Games since 1945 have had event spaces concentrated so completely at fringe locations, but several have used extensive suburban sites. The Olympic Park for Athens 2004 was constructed on the site of 
an earlier sports complex at Maroussi, a suburban municipality nine kilometres north-east of the city centre; Rio de Janeiro 2016 had its Olympic Park at Barra da Tijuca amidst middleclass suburbia in the west of the city. The attractions in each case are similar: availability of sufficient but lower-cost land from existing recreational, woodland or agricultural uses; ease of construction; and lack of restrictive ordinances, which compensate for needing to provide new transport links to connect to the urban core.

The final option, use of remediated land, has long featured in staging World's Fairs (e.g. Santomasso, 1980; Sabat, 2014), but has only recently impinged in any significant manner on the locational decisions of Olympic cities. The reasons for heightened interest in the last two decades lie primarily in the convergence of three trends. The first was recognition that remediated land offered the possibility of finding conveniently located land without the problems of mass evictions or complex litigations. Secondly, remediation accorded with the Olympic movement's adoption of more positive and proactive attitudes towards the environment. Extending back to the early 1990s, this saw acceptance of 'environment' as a 'third pillar' of the Olympic movement's core philosophy of Olympism alongside 'sport' and 'culture', with the Olympic Charter amended in 1996 to commit the IOC 'to encourage and support a responsible concern for environmental issues, to promote sustainable development in sport and require that the Olympic Games are held accordingly' (quoted in Pitts and Liao, 2009, 67; see also Samuel and Stubbs, 2013). Thirdly, it was increasingly believed that considerations of productive post-event legacy use could counterbalance higher costs of site preparation. The combined weight of these considerations would see a spate of both Winter and Summer Games using brownfield sites. For example, the trend towards split-site (mountain resort-lowland city) arrangements for the Winter Olympics saw large cities such as Turin 2006 and Vancouver 2010 using substantial brownfield sites to house event spaces and venues (Laski, 2009; Essex and de Groot, 2017). For the Summer Games, the use of remediated land would figure most prominently at Sydney 2000 and London 2012; the two case studies to which we now turn.

\section{Implementing Remediation}

Although never having a priori commitment to remediation as the preferred option for an Olympic Park, Sydney's path when bidding effectively progressed from 'one brickpit to another' (Little, 1997). A 1962 scheme designed to signal intent to host an Olympics proposed developing large-scale stadia, an aquatics centre and indoor arena on 16 hectares of brickfield land at St Peter's in southern Sydney. When that initiative foundered, the underlying principle of creating a site capable of staging an Olympics reemerged when residents fiercely opposed a plan to redevelop the existing sports district at Moore ParkCentennial Park in readiness to bid for the 1988 Games. A specially appointed commission then scrutinized 20 possible sites in the metropolitan area before, in 1973, recommending Homebush Bay, 14 kilometres west of Sydney's city centre on the Parramatta River (Weirick, 1999).

While described alluringly as 'a waterfront site in the demographic heart of Sydney' (SOCOG, 2000, 11) and benefitting from being principally state-owned land, Homebush Bay posed considerable problems. Originally a richly diverse wetland and scrub ecosystem, the land was severely damaged due to the dumping of untreated household and industrial 
waste and the activities of occupants, past and present, that included shipbreakers, chemical industries, a saltworks, Australia's largest abattoir, the Newington naval armaments depot and the state brickworks. The shallow bay often spawned algal blooms, dangerous concentrations of heavy metals and dioxins resided in the estuarine sediments, and deposits of live ordnance were not fully recorded. The instability of the landfill sites would also pose severe problems for building (Weirick, 1999, 76).

No bid materialized for 1988, but sustained remedial work began at Homebush Bay, both to accommodate possible future bids and because many industrial activities had reached the end of their productive lives (Figure 1). This phase produced the biodiverse Bicentennial Park, a technology park and an aquatic centre (Cashman, 2008, 28). When attention turned to the 2000 Games, the bid team initially made little of Homebush Bay's blight lest that might be seen as a disadvantage, but any nervousness on that score evaporated once it was realised that IOC thinking had changed. As Rod McGeoch, leader of the 2000 bid team, recalled: 'When we went to Lausanne for a briefing on the bid books, we noticed that the environment was listed as a full chapter in its own right for the first time'. It was the team's 'good fortune' that strong affirmation of green credentials and the promised remediation of an environmental contaminated area successfully addressed the IOC's emerging concerns (McGeoch and Korporal, 1994, 139; also Kearins and Pavlovich, 2002).

***FIGURE 1 about here***

Acceptance of the bid saw preliminary work to treat toxic waste and undertake water table and wetland management (Figure 2), but chemical remediation of the site proved more difficult than anticipated. Conscious of timing, the Olympic Coordinating Authority bulldozed nine million cubic metres of contaminated fill into 11 heaps rather than attempt full cleansing. The mounds were covered with clay and landscaped, with five designed to provide observation points for visitors. Subsurface drainage systems attempted to capture seepage from the mounds before it reached the water table or creeks. Continuing questions, however, remained as to the quality of the remedial work (Beder, 1994; Lenskyj, 2002; Berlin, 2003) and the efficacy of burying 'so much toxicity beneath a metre of dirt and a mountain of public relations' (Chipperfield, 2000).

***FIGURE 2 about here***

London's experience resonated with Sydney, both by choosing to remediate land and because, as Neale Coleman (2018) suggested: 'For all of us working on delivering the London 2012 Olympic and Paralympic Games, the triumphant Sydney 2000 was our exemplar'. London had previously hosted the Games in 1908 and 1948 at sites in west London, but by the late-1970s attention had switched eastwards, with an exploratory study earmarking 200 hectares in the recently-closed Royal Docks for a possible Olympic Park (GLC, 1979). That proposal, nominally for 1988 , failed to materialize and that specific site was overtaken by London's Dockland regeneration. In addition, the abolition of the city's unitary authority in 1985 delayed any further bidding until the creation of the Greater London Assembly in 2000 permitted the revival of interest. 
Analysis of the 2012 bid documents effectively reflects the team's judgment as to the extent to which legacy had become intrinsic to IOC thinking. The Olympic Park would be a heavily polluted 246-hectare site in the Lower Lea Valley at Stratford, located in the midst of multicultural districts that ranked among the poorest in England (Evans and Edizel, 2016). Locating there blended arguments about physical and social regeneration into an emotionally powerful combination. More than just fast-track urban regeneration, development would also deploy megaevent investment as a vehicle to address multiple deprivation and social inequality. In doing so, the IOC would gain a shining example of the wider benefits that might follow the award of its most prestigious festival (Evans, 2014).

Like Homebush Bay, the Lower Lea Valley had a marginality born of an industrial past that included milling, porcelain, chemical, leather, cosmetic, match- and paint-manufacture, and locomotive and carriage fabrication. Sulphur, phosphorous, ammonia and coal products were stored onsite, with approved landfill of toxic waste. After London won the bid in July 2005 and land acquisition was complete, remediation received immediate attention. Undertaken by a newly created Olympic Delivery Authority rather than by the existing arms of local government, it followed a five-step programme, beginning with site investigation and creation of a global remediation strategy to establish site-wide principles through to implementation of remediation design and checking to show effectiveness (Hou et al, 2015, 63-64). One million cubic metres of contaminated soil were cleansed, albeit at steadily rising cost (Macrury and Poynter, 2008), with 90 per cent reused on site (Figure 3). Other works included reconfiguring the meandering water courses (Figure 4) and removing redundant buildings and other signs of post-industrial decline. The lines of electricity pylons that crisscrossed the site were removed by burying the cables. As with Homebush Bay, discoveries of hitherto unknown deposited materials required costly treatment. These included previously unrecorded quantity of vinyl chloride and radioactive waste that had been illegally dumped (Anon, 2010).

***FIGURES 3-4 about here ${ }^{* * *}$

\section{The Limits of Masterplanning}

The legacy phase of any recent Olympics involves two initial sets of decisions. The first concerns finance. If there is no preassigned fund in place - almost certainly from the public purse - then the legacy proposition will need to be attractive to the private sector. If that is not the case, then compromise is almost inevitable if white elephants are to be avoided. The second involves negotiating the hybrid status of the key event spaces, delicately balancing the desire to give physical expression to memories of a globally prestigious event while keeping an eye on the legacy landscapes to follow.

Choosing remediated land adds further opportunities and constraints. Strictly speaking neither Olympic Park was a tabula rasa; the Lower Lea Valley, for example, contained around 300 businesses (employing 2500 people), allotments and a vibrant cluster of around 140 artists' studios were still in place (Evans, 2016). Nevertheless, to the outsider both areas appeared inchoate and were widely perceived as being blank slates; an understanding that facilitated a style of masterplanning unusual for an age characterized by a retreat from planning. In both cases, there were explicit statements that imaginative 
design could create 'a new piece of city' (see Cashman, 2015, 102; Burrows, 2017). The dominant approach, however, was 'top-down'. Planners freely drew on Olympic and sporting connections, local history and ideas garnered from wider planning practice when undertaking 'placemaking', interpreted here as that part of the design process that selfconsciously seeks to create distinct and meaningful identities for given localities (Relph, 1976, 63-78; Horvath, 2004; Markusen and Gadwa, 2010; Mansilla and Milano, 2019). However, despite initiatives such as a public competition to select suitable names for neighbourhoods in what is now the London's Queen Elizabeth Olympic Park (QEOP), there was little attempt in either city to undertake wider public participation exercises that engaged with the "experience" and "feeling" of places in order to influence and enhance community dynamics (Cilliers and Timmermans, 2014, 413; Hayden, 1995).

With regard to Sydney the comprehensive agency required to undertake legacy planning appeared belatedly, with the Sydney Olympic Park Authority (SOPA) only created in 2001. Understandably perhaps, the physical and symbolic restructuring needed to yield a legacy of world-class sporting arenas and commercial hubs initially lagged far behind aspirations (Dunn and McGuirk, 1999; Cashman, 2015). For all that the staging of the 2000 Games had achieved in terms of delivery, organisation and raising the city's international profile (Cashman, 2008), the major stadia lacked appeal to private-sector operators and had seemingly achieved white elephant status. The Park itself had the appearance of a ghost town. Tourists were in short supply and affordable housing construction failed to meet targets. The short-cuts taken with land remediation had rebounded, necessitating further work to correct abiding problems (Suh et al, 2011).

Struggling to come to terms with post-event realities, SOPA juggled long-established concerns with residential, commercial, ecological and cultural elements with what Freestone and Gunasekara $(2017,325)$ identified as the 'three key ingredients from...[the] post-Games vision'. These were: new development to build up the daily workforce base; 'building on the carnival and festival atmosphere' to continue to attract entertainments and sporting events; and 'cultivating a green oasis through progressive development of the Parklands'. Three master plans would appear in the period up to 2010, by which point the legacy time-frame had lengthened from an initial 7-10 years to around 30 years.

The Master Plan 2030, produced in 2010 and still the working framework (SOPA, 2018), envisaged a precinctual development plan; transforming the 'broad, open spaces characteristic of megaevents' (Sanchez and Essex, 2018, 285) into smaller 'human-scale' development, urban units, catering for 23500 new residents and supplying 34000 jobs and 100,000 square metres of retail space. In structural terms, application of precinctual design here, as elsewhere in the Sydney region (e.g., see Searle et al, 2014; Budge, 2019), oriented legacy planning towards practices that in principle favoured densification, mixed employment, enhanced community involvement in the public domain and commitment to sustainability. Viewed positively, considerable progress has been made in attracting housing development, finding users for the venues, and creating an important new suburban economic hub that draws on the 'legacy of vacant remediated public land, rail access, sporting venues and abundant parkland left by the Games' (Searle, 2012, 201). Place identity was also assisted by the Olympic Park gaining formal identity in 2009 as an official suburb of Sydney's metropolitan area. However, critics note that the disjointed approach to 
legacy commitments, born of the specific circumstances of the remediated site and the late onset of legacy planning, relied on 'retro-fitting usable features into spaces for which they were not designed' (Sanchez and Essex, 2018, 285). Problems remain too in reshaping patterns of transport provision and in resolving tensions between sustainable legacy and a pro-development neoliberal ideology (Freestone and Gunasekara, 2017, 325).

Learning from negative as well as positive features of Sydney 2000, London 2012 represented the first time that a Summer Olympics host city launched its legacy agency before the Games. The Olympic Park Legacy Company (established in May 2009) and then the London Legacy Development Corporation (founded in 2012) took charge of a masterplanning process originally initiated in 2005 , when two masterplans - one for the Games and another called the 'Olympic Legacy Transformation Masterplan' - were commissioned (Davis, 2019, 881). The first definitive Legacy Master Plan, published in 2010, would cover a London inner-city district now given the postcode E20. It retained the five planned sporting venues, with the Athletes' Village and the Media Centre converted respectively for flats and cultural sector activities. To these would be added five new residential neighbourhoods, associated educational and social facilities, and employment and entertainment hubs. These would exist within a broad two-zone schema, with the northern part of the QEOP featuring open space and emphasising outdoor recreation and biodiversity; the southern being more densely developed with most of the employment nodes and formal leisure and events spaces.

Yet despite gestures implying continuity, such as efforts to align toponymy with the site's Olympic or industrial past, fundamental changes have occurred. While the broad outlines of the original Master Plan remain in force, fulfilment of planned objectives always relied on attracting private investment with the attendant constraints noted above. The QEOP now plays host to a plethora of private sector companies and agencies, including Qatari Diar Delancey (who in partnership with other financial interests manages the private rental sector in the East Village); masterplanners such as Sheppard Robson with Studio Egret West working on the new Sweetwater and East Wick neighbourhoods and developers such as Wimpey, L\&Q, Balfour Beatty and Places for People involved in specific projects. All have their own agendas when seeking to capitalise on the creation of the QEOP. With the remediated land now prime real estate, pressure for change mounted, especially for those parts of the QEOP close to the transport hubs in the south. For example, target figures for housing in the proposed Marshgate Wharf residential neighbourhood were slashed when it was decided to create a new Cultural and Educational District that was, in itself, never part of the original legacy plans (Gold and Gold, 2017). While the changes can be presented as promoting city-wide benefit with attraction of new academic and cultural sector occupants that will include offshoots of UCL, the University of the Arts, Sadler's Wells, the Victoria and Albert Museum and the Smithsonian Institution, and the BBC, the cuts in the housing targets have implications beyond mere statistics. Reductions especially in the housing designated as 'affordable' - a term that has proven 'notoriously hollow' in light of the rent levels deemed appropriate (Nowicki and Harris, 2019) - mean that questions are posed about the potential impact on 'the urgent need for genuinely affordable housing in the area' (Bernstock, 2014, 135). That in itself is a token of concern that important aspects of the social legacy will never be delivered (e.g. see Evans, 2016; Cohen and Watt, 2017). 


\section{Conclusion}

This discordant note again points to wider issues of narration and appraisal. Questions of legacy are judged on their merits in terms of local impact, potential and actual, but they also constitute elements in broader arguments about the nature, propriety and effectiveness of megaevent-led interventions in the urban environment. For the IOC, the visionary dimension occupies an important role in arguments about what Olympic-led urban regeneration can mean for the host city. The physical transformations of the remediated sites seen at Homebush Bay and in the lower Lea Valley are depicted heroically; blank slates on which the march towards ever greater progress and achievement is etched (Gold and Gold, 2011, 123). The IOC's guidance document on Olympic Legacy, for example, argued that: 'Some of the most tangible legacies....are the regenerated and enhanced sites within the host city' (IOC, 2012, 32-33). Sydney 2000 and London 2012 are singled out for creating public parks around the venues 'for community enjoyment' and for providing new habitats for wildlife, including wetland areas, open river banks and grasslands that foster biodiversity and 'accessible and usable space for the community' (ibid, 33). In the economic field, the document singles out significant benefits from job creation in the construction industry in the lead up to the Games and in the subsequent transformation of the park to legacy use as well as the establishment of new areas of office and commercial activity (ibid, 52). Urban transformation brought by land remediation, therefore, emerges as much a vehicle for delivering the Good Life as for improving the built environment.

For their part, the respective legacy agencies echo similar themes. London proclaimed the transformation of a 'polluted industrial site and a barrier to urban renewal' into places for 'Londoners who want to live and work without a long commute and raise a family in a stable urban community' and enjoy a 'healthy and sustainable lifestyle, anchored by sports and active living' (OPLC, 2012, 3; LLDC, 2014, 6, 12). This vision was extended to embrace the cultural and educational investment that would create a 'new powerhouse for innovation, creativity and learning' branded East Bank (QEOP, 2019). Sydney saw 'marginal dumping grounds for debris' changed by planned action into the 'focal point of Sydney's recreational activities' (Coltheart, 2001,6). Brownfield sites were 'badlands' in all senses of that word. Facing up to their problems decisively and building for the future could deliver not just improvement, but also redemption.

For critics, the visionary trope is deconstructed in various ways. For example, Powell and Marrero-Guillamón (2012) pointed to the 'silenced history' of the Lower Lea Valley as a prerequisite for thinking of the area as an undifferentiated brownfield space. Here and elsewhere, the Games are seen as providing an opportunity to appropriate land from local communities in the long-term interests of property development and facilitate gentrification (Allen and Cochrane, 2014). For others, the historical circumstances of remediation are treated as secondary since, if the necessary works and costings have been handled properly, remediation should simply provide a platform that would take its lasting meaning from the development that ensued (Bernstock, 2014; Cohen and Watt, 2017; Davies, 2019). The amount of effort and commitment necessary to achieve remediation is downplayed, pointing out, first, that significant regeneration was already occurring in both cases and, secondly, the results are insufficient to justify what they regard as the excessive size of Games-related investment. 
The extent to which resistance to involvement in Olympic projects has mounted suggests that lessons such as these have had an impact (Lenskyj, 2008; Talbot, 2019). Yet although critics continue to dispute the validity and effectiveness of using megaevents to fast-track urban development, in the final analysis Sydney and London are represented as the two best advertisements from the twenty-first century's Games as to what Olympic-led urban regeneration can mean for the host city. Although the long trajectory of Olympic legacy has yet to run its course, in both cases the dramatic physical transformation of the remediated sites is interpreted as vindication of core Olympic values by the IOC and as evidence of dynamic urban governance by the host cities. As such, their experience provides ideological fodder that helps to counter other examples, such as Athens 2004 or Rio de Janeiro 2016, where the international press serves up a steady diet of images of abandoned venues or underutilised Athletes' Villages. At a time when finding new host cities has become increasingly difficult, the power of such transformatory narratives cannot be overestimated.

\section{Acknowledgements}

Our thanks to Professor Rob Freestone for supplying us with two of the photographs reproduced here and to two anonymous referees for their helpful and incisive comments.

\section{References}

Adams, D., Disberry, A., Hutchison, N. and Munjoma, T. (2002). Brownfield land: owner characteristics, attitudes and networks. In Rydin, Y. and Thornley, A. eds. Planning in the UK: agendas for the new millennium. London: Routledge, pp. 317-336.

Alker, S., Joy, V., Roberts, P. and Smith, N. (2000). The definition of brownfield. Journal of Environmental Planning and Management, 43, pp. 49-69. doi: 10.1080/09640560010766

Allen, J., and Cochrane, A. (2014) The urban unbound: London's politics and the 2012 Olympic Games. International Journal of Urban and Regional Research, 83, pp. 1609-1624. doi: 10.1111/1468-2427.12147.

Anon (2010). Clearing toxic waste from London 2012 site cost $£ 12.7 \mathrm{~m}$. Available online at: https://www.bbc.co.uk/news/uk-england-london-11750688, accessed 19 November 2018.

Bagaeen, S.G (2006). Brownfield sites as building blocks for sustainable urban environments: a view on international experience in redeveloping former military sites. Urban Design International, 11, pp. 117-128. doi:10.1057/palgrave.udi.9000168.

Bäing, A.S. and Wong, C. (2018). The impact of brownfield regeneration on neighbourhood dynamics: The case of Salford Quays in England. Town Planning Review, 89, pp. 513-534. doi: 10.3828/tpr.2018.33 
Banzhaf, E., Arndt, T. and Ladiges, J. (2018). Potenziale städtischer Gewerbebrachflächen für eine integrierte Stadtentwicklung: Monitoring für ein nachhaltiges Flächenmanagement am Beispiel der wieder wachsenden Stadt Leipzig. disP: the Planning Review, 54, pp. 26-43. doi: 10.1080/02513625.2018.1487643

Beder, S. (1993). Sydney's toxic green Olympics. Current Affairs Bulletin, 70(6), pp. 12-18.

Berlin, P. (2003). What did the Olympics bring Sydney? New York Times, 24 December. Available online at:

http://www.nytimes.com/_2003/12/24/news/24iht-t1_2.html, accessed 19 January 2019.

Bernstock, P. (2014). Olympic Housing: a critical review of London 2012's legacy. Farnham: Ashgate.

Bjelland, M.D. (2004). Brownfield sites in Minneapolis-St. Paul: the interwoven geographies of industrial disinvestment and environmental contamination. Urban Geography, 25, pp. 631-57. doi: 10.2747/0272-3638.25.7.631.

Bliek, D. and Gauthier, P. (2007). Mobilising urban heritage to counter the commodification of brownfield landscapes: lessons from Montréal's Lachine Canal. Canadian Journal of Urban Research, 16 (Supplement), pp. 39-58.

Bond, S. (2001). Stigma assessment: The case of a remediated contaminated site. Journal of Property Investment and Finance, 19, pp. 188-212. doi: 10.1108/14635780110383721

Brownill, S. (2013). Just add water: waterfront regeneration as a global phenomenon. In Leary, M.E. and McCarthy, J. eds., Routledge Companion to Urban Regeneration, London: Routledge, pp. 45-55.

Budge, K. (2019). Making in the City: disjunctures between public discourse and urban policy. Australian Geographer, 50, 185-199. doi: 10.1080/00049182.2018.1503045

Burrows, T. (2017). Legacy, what legacy? Five years on the London Olympic park battle still rages. Available online at: https://www.theguardian.com/cities/2017/jul/27/londonolympic-park-success-five-years-depends. Assessed 16 June 2019.

Campo, D. (2019). Rustbelt insurgency and cultural preservation: how guerrilla practices saved the blast furnaces and the automobile factory. Urban Design International, doi: 10.1057/s41289-019-00089-3.

Carné, J. and Ivancic, A. (2008) The Barcelona Model: 1979-2004 and beyond, in Jenks, M. Kozak, D. and Takkanon, P. eds., World Cities and Urban Form: fragmented, polycentric, sustainable?, London: Routledge, pp. 129-46.

Cashman, R. (2008). The Sydney Olympic Park model: its evolution and realization. In Hay, A. and Cashman, R. (eds) Connecting Mega Events Cities: a publication for the $9^{\text {th }}$ World Congress of Metropolis. Sydney: Sydney Olympic Park Authority, pp. 21-39. 
Cashman, R. (2011). Sydney Olympic Park, 2000 to 2010: history and legacy. Sydney: Walla Walla Press.

Cashman, R. (2015). Sydney Olympic Park, 2000 to 2010. In Holt, R. and Ruta, D., eds. Routledge Handbook of Sport and Legacy: meeting the challenge of major sports events. Abingdon: Routledge, pp. 99-110.

Cenci, J. (2018). From factory to symbol: identity and resilience in the reuse of abandoned industrial sites of Belgium. Historic Environment: Policy and Practice, 9, pp. 158-174. doi: 10.1080/17567505.2018.1506017.

Chappelet, J.-L. (2012). Mega sporting event legacies: a multifaceted concept. Papeles de Europa, 25, pp. 76-86. doi: 10.5209/rev_PADE.2012.n25.41096

Chipperfield, M. (2000). Sydney in bad odour over toxic backyard for Olympic Games, The Telegraph, 27 August. Available online at:

https://www.telegraph.co.uk/news/worldnews/australiaandthepacific/1367883/Sydney-inbad-odour-over-toxic-backyard-for-Olympic-Games.html, accessed 19 November 2018.

Cilliers, E. J., \& Timmermans, W. (2014). The Importance of Creative Participatory Planning in the Public Place-Making Process. Environment and Planning B: Planning and Design, 41, 413-429. doi: 10.1068/b39098

Cohen, P. and Watt, P., eds. (2017). London 2012 and the Post-Olympics City: a hollow legacy?. Basingstoke: Palgrave Macmillan

COHRE (2007). Fair Play for Housing Rights: Mega-Events, Olympic Games and Housing Rights. Geneva: Centre on Housing Rights and Evictions.

Coleman, N. (2018). Park Life: London 2012 and lessons in placemaking, available online at: https://www.lendlease.com/au/better-places/park-life-london-2012-and-lessons-inplacemaking/, accessed 18 July 2019.

Coltheart, L. (2001). Making the Magic: an outline history of the Olympic Coordination Authority NSW. Sydney: Olympics Coordination Authority.

Davies, J. (2019). Futurescapes of urban regeneration: ten years of design for the unfolding urban legacy of London's Olympic Games, 2008-2018. Planning Perspectives, 34, pp. 877901. doi: 10.1080/02665433.2018.1541757

De Certeau, M. (1984). The Practice of Everyday Life. Berkeley: University of California Press.

De Sousa, C. (2017). Trying to smart-in-up and cleanup our act by linking regional growth planning, brownfields remediation, and urban infill in Southern Ontario cities. Urban Planning, 2(3), pp. 5-17. doi: 10.17645/up.v2i3.1026 
Dickinson, P., Johnston, K. and Zaiontz, K., eds. (2016). Mega-event cities:

art/audiences/aftermaths, Public, 53, 5-197.

Dixon, T. (2006). Integrating sustainability into brownfield regeneration - rhetoric or reality? an analysis of the UK development industry, Journal of Property Research, 23, pp. 237-267. doi: 10.1080/09599910600933889.

Dixon, T., Raco, M., Catney, P. and Lerner, D.N., eds. (2007). Sustainable Brownfield Regeneration: liveable places from problem spaces. Chichester: Wiley.

Dixon, T., Otsuka, N. and Abe, H. (2013). Critical success factors in urban brownfield regeneration: bringing 'hardcore' sites in Manchester and Osaka back into use. In Leary. M.E. and McCarthy, J. eds., Routledge Companion to Urban Regeneration. Abingdon: Routledge, pp. 241-50.

Dorstewitz, P. (2014). Planning and experimental knowledge production: Zeche Zollverein as an urban laboratory. International Journal of Urban and Regional Research, 38, pp. 431-449. doi: 10.1111/1468-2427.12078

Dunn, K.M. and McGuirk, P.M. (1999). Hallmark events. In R. Cashman and A. Hughes, eds., Staging the Olympics: The Event and its Impact. Sydney: Walla Walla Press, pp. 18-32.

Essex, S. and Chalkley, B. (1998). Olympic Games: catalyst of urban change, Leisure Studies, 17, pp. 187-206. doi: 10.1080/026143698375123.

Essex, S. and Chalkley, B. (2004). Mega-sporting events in urban and regional policy: a history of the winter Olympics. Planning Perspectives, 19, pp. 201-32. doi: 10.1080/0266543042000192475

Essex, S.J. and de Groot, J. (2017). The Winter Olympics: driving urban change, 1924-2022. In Gold, J.R. and Gold, M.M., eds. Olympic Cities: city agendas, planning and the World's games, 1896-2020. Abingdon: Routledge, pp. 64-89.

Evans, Gillian (2016). London's Olympic Legacy: the inside track. Basingstoke: Palgrave Macmillan.

Evans, Graeme (2014). Designing legacy and the legacy of design: London 2012 and the Regeneration Games. Architectural Research Quarterly, 18, pp. 353-366. doi: 10.1017/S1359135515000081.

Evans, Graeme and Edizel, Ö. (2017). London 2012. In Gold, J.R. and Gold, M.M., eds. Olympic Cities: city agendas, planning and the World's games, 1896-2020, 3rd edition. Abingdon: Routledge, 359-389.

Freestone, R. and Gunasekara, S. (2017). Sydney 2000. In Gold, J.R. and Gold, M.M., eds. Olympic Cities: city agendas, planning and the World's games, 1896-2020, 3rd edition. Abingdon: Routledge, pp. 317-332. 
Gaffney, C. (2013). Between discourse and reality: The un-sustainability of mega-event planning. Sustainability, 5(9), pp. 3926-3940. doi: 10.3390/su5093926

Gemmill, J.H. (2012). The role of an agency in setting the policy agenda. Unpublished PhD thesis, Auburn, AL: Auburn University. Available online at:

https://etd.auburn.edu/bitstream/handle/10415/3125/GemmillDissertation\%2005072012.fi nal.pdf?sequence=2\&ts=1437112033083, accessed 12 November 2018.

Genske, D.D. (2003). Urban Land: degradation-investigation-remediation, Berlin: Springer.

Gilbert, A. and Hall, E. (2014). The true cost of brownfield land: rethinking investment approaches. Journal of Urban Regeneration and Renewal, 8, pp. 79-85.

Girginov, V. (2018). Rethinking Olympic Legacy. Abingdon: Routledge.

Giulianotti, R. (2013) Six security legacies of major sporting events. ICSS Journal, 1, pp. 95101.

GLC (1979). 1988 Olympic Games: Feasibility Study. London: Greater London Council.

Gold, J.R. and Gold, M.M. (2005). Cities of Culture: Staging International Festivals and the Urban Agenda, 1851-2000. Farnham: Ashgate.

Gold, J.R and Gold, M.M., eds (2007). Olympic Cities: urban planning, city agendas and the World's games, 1896-2012, London: Routledge.

Gold, J.R. and Gold, M.M. (2008). Olympic Cities: regeneration, city rebranding and changing urban agendas. Geography Compass, 2, pp. 300-18. doi: 10.1111/j.1749-8198.2007.00080.x

Gold, J.R. and Gold, M.M. (2009). Future indefinite?: London 2012, the spectre of retrenchment and the challenge of Olympic sports legacy. London Journal, 34, pp.180-197. doi: $10.1179 / 174963209 \times 442450$.

Gold, J.R. and Gold, M.M., eds. (2012). The Making of Olympic Cities, 4 vols. London: Routledge.

Gold, J.R. and Gold, M.M. (2017). Olympic futures and urban imaginings: from Albertopolis to Olympicopolis. In Hannigan, J. and Richards, G. eds., The Handbook of New Urban Studies. London: Sage, pp. 514-34.

Gold, J.R. and Gold, M.M. (2018). Urban segments and event spaces: World's Fairs and Olympic sites. In Hein, C., ed. The Routledge Handbook of Planning History. Abingdon: Routledge, pp. 348-63.

Grix, J., ed. (2017). Leveraging Mega-event Legacies. Abingdon: Routledge. 
Hall, T. and Hubbard, P., eds. (1998). The Entrepreneurial City: geographies of politics, regime and representation. Chichester: Wiley.

Harnik, P. and Donahue., R. (2011). Turning brownfields into parks, green grass and greenbacks in unexpected spots: a sustaining places story. Planning, 77(10), pp. 13-17. doi: 10.1215/03616878-2008-008

Harnik, P., Taylor, M. and Welle, B. (2006). From dumps to destinations: the conversion of landfills to parks. Places, 18, pp. 83-88.

Hayden, D. (1995). The Power of Place: Urban Landscapes as Public History. Cambridge, MA: MIT Press.

Hayek, M., Arku, G. and Gilliland, J. (2010). Assessing London, Ontario's brownfield redevelopment effort to promote urban intensification. Local Environment, 15, pp. 389-402. doi: 10.1080/13549831003677712.

Hayes, G. and Karamichas, J., eds. (2011). Olympic Games, mega-events and civil societies: globalization, environment, resistance. Berlin: Springer.

Heatherington, C. Jorgensen, A. and Walker, S. (2019). Understanding landscape change in a former brownfield site. Landscape Research, 44, pp. 19-34. doi:

10.1080/01426397.2017.1374359

Hiller, H. (2006). Post-event outcomes and the post-modern turn: the Olympics and urban transformations. European Sport Management Quarterly, 6, pp. 317-32.

https://doi.org/10.1080/16184740601154458.

Holt, R. and Ruta, D., eds (2015). Routledge Handbook of Sport and Legacy: meeting the challenge of major sports events. Abingdon: Routledge.

Horne, J.D. (2017). Sports megaevents: three sites of contemporary political contestation. Sport in Society, 20, pp. 328-340. doi: 10.1080/17430437.2015.1088721.

Horvath, R.J. (2004). The particularity of global places: Placemaking practices in Los Angeles and Sydney. Urban Geography, 25, pp. 92-119. doi: 10.2747/0272-3638.25.2.92.

Hou, D. and Al-Tabbaa, A. (2014). Sustainability: a new imperative in contaminated land remediation. Environmental Science and Policy, 39, pp. 25-34. doi:

10.1016/j.envsci.2014.02.003

Hou, D., Al-Tabbaa, A. and Hellings, J. (2015). Sustainable site clean-up from megaprojects: lessons from London 2012. Proceedings of the Institution of Civil Engineers-Engineering Sustainability 168, 61-70. doi: 10.1680/ensu.14.00025.

Illas, I. (2012). Thinking Barcelona: ideologies of a global city. Liverpool: Liverpool University Press. 
IOC (2003). Olympic Games Study Commission: Report to the $115^{\text {th }}$ IOC Session, Prague, July, 2003. Lausanne: International Olympic Committee.

IOC (2012). Olympic Legacy, Lausanne: International Olympic Committee.

IOC (2019). Olympic Agenda 2020. Available online at: https://www.olympic.org/olympicagenda-2020

Karamichas, J. (2013). The Olympic Games and the Environment. Berlin: Springer.

Kearins, K. and Pavlovich, K. (2002). The role of stakeholders in Sydney's Green Games. Corporate Social Responsibility and Environmental Management, 9, pp. 157-169. doi: 10.1002/csr.19.

Larner, W. (2003). Neoliberalism?. Environment and Planning D: Society and Space, 21, pp. 509-12.

Laski, J. (2009). Towards a greener Olympics: sustainable development and the Vancouver 2010 Athletes Village at Southeast False Creek. Journal of Environmental Law and Practice, 20, pp. 37-60.

Lee, T.-P. (2015). Brownfield redevelopment justice. Taiwanese Political Science Review, 19, pp. 1-58.

Leger, C., Balch, C. and Essex, S. (2016). Understanding the planning challenges of brownfield development in coastal urban areas of England. Planning Practice and Research, 31, pp. 119-31. doi: 10.1080/02697459.2016.1146428

Lenskyj, H.J. (2002). The Best Olympics Ever?: Social Impacts of Sydney 2000. Albany: State University of New York Press.

Lenskyj, H. J. (2008). Olympic Industry Resistance: Challenging Olympic power and propaganda. Albany: SUNY Press.

Leopkey, B. and Parent, M.M. (2012). Olympic Games legacy: from general benefits to sustainable long-term legacy. International Journal of the History of Sport, 29, pp. 924-943. doi: 10.1080/09523367.2011.623006

Loures, L. and Vaz, E. (2018). Exploring expert perception towards brownfield redevelopment benefits according to their typology. Habitat International, 72, pp. 66-76. doi: 10.1016/j.habitatint.2016.11.003

Macrury, I. and Poynter, G. (2008). The regeneration games: Commodities, gifts and the economics of London 2012. International Journal of the History of Sport, 25, pp. 2072-2090. doi: 10.1080/09523360802439254. 
Mangan, J.A. (2008). Prologue: guarantees of global goodwill: post-Olympic legacies - too many limping white elephants?. International Journal of the History of Sport, 25, 1869-83. doi: 10.1080/09523360802496148.

Mansilla, J.A. and Milano, C. (2019). Becoming centre: tourism placemaking and space production in two neighbourhoods in Barcelona. Tourism Geographies, published online 23 February, doi: 1080/14616688.2019.1571097

Markusen, A. and Gadwa, A. (2010). Creative Placemaking. Washington, DC: Markusen Economic Research Services and Metris Arts Consulting.

Marshall, T. (2000) "Urban planning and governance: is there a Barcelona Model?," International Planning Studies, 5, 299-319.McGrath, D.T. (2000). Urban industrial land redevelopment and contamination risk. Journal of Urban Economics, 47, pp. 414-442.

McGeoch, R., with Korporal, G. (1994). The Bid: how Australia won the 2000 Games. Port Melbourne: Heinemann.

Meuser, H. (2013). Soil Remediation and Rehabilitation: treatment of contaminated and disturbed land. Berlin: Springer.

Monclús, F.-J. (2003). The Barcelona Model: an original formula?: from "reconstruction" to strategic urban projects (1979-2004). Planning Perspectives, 18, pp. 399-421.

Moragas, M. de, Kennett, C. and Puig, N., eds. (2003). The Legacy of the Olympic Games 1984-2000: International Symposium, Lausanne, 14th, 15th and 16th November 2002. Lausanne: International Olympic Committee.

Müller, M. (2015). The mega-event syndrome: why so much goes wrong in mega-event planning and what to do about it. Journal of the American Planning Association, 81, pp. 617. doi: $10.1080 / 01944363.2015 .1038292$.

Nijkamp, P., Rodenburg, C.A. and Wagtendonk, A.J. (2002). Success factors for sustainable urban brownfield development: a comparative case study approach to polluted sites. Ecological Economics, 40, pp. 235-252. doi: 10.1016/S0921-8009(01)00256-7.

Nowicki, M. and Harris, E. (2019) Talk of a public housing renaissance in London is fake news. The Guardian. Available online at: https://www.theguardian.com/society/2019/aug/13/talk-public-housing-renaissancelondon-fake-news-housing-crisis, accessed 15 August 2019.

Pavoni, A. (2015). Resistant legacies. Annals of Leisure Research, 18, pp.470-490.

Pitts, A. and Liao, H. (2009). Sustainable Olympic Design and Urban Development. Abingdon: Routledge. 
Powell, H. and Marrero-Guillamón, I. (2012). The Art of Dissent: adventures in London's Olympic state. London: Marshgate Press.

Preuss, H. (2015). A framework for identifying the legacies of a mega sport event. Leisure Studies 34, pp. 643-64. doi: 10.1080/02614367.2014.994552

QEOP (2019) East Bank. Available online at:

https://www.queenelizabetholympicpark.co.uk/the-park/attractions/east-bank

Raco, M. (2014). Delivering flagship projects in an era of regulatory capitalism: state led privatization and the London Olympics 2012. International Journal of Urban and Regional Research 38, pp.176-97. doi: 10.1111/1468-2427.12025

Reeves, B. (2011). The Don Steel Works and Saville Works: charting the growth of the small Sheffield steel firm. Industrial Archaeology Review, 33, pp. 58-73. doi:

10.1179/174581911X13070247656543

Relph, T. (1976). Place and Placelessness. London: Pion.

Roche, M. (2002). Megaevents and Modernity: Olympics and Expos in the growth of global culture. London: Routledge.

Roult, R. and Lefebvre, S. (2013). Stadiums, public spaces and mega-events: cultural and sports facilities as catalysts for urban regeneration and development. In Leary, M.E. and McCarthy, J. eds., Handbook of Urban Regeneration. Abingdon: Routledge, pp. 548-57.

Ryan, K.L. (1998). Toxic turnabouts: news from the brownfields. Planning, 64, pp. 20-23.

Sabat, M. (2014). Panorama: Robert Moses modern city and the New York World's Fairs. In Hollengreen, L., Pearce, C., Rouse, R. and Schweizerin, B. (eds) Meet me at the Fair: a World's Fair Reader. Pittsburgh, PA: the Editors and ETC Press, pp. 281-88.

Samuel, S. and Stubbs, W. (2013). Green Olympics, green legacies? An exploration of the environmental legacies of the Olympic Games, International Review for the Sociology of Sport, 48, 485-504. doi: 10.1177/1012690212444576.

Sanchez, R.L. de Oliveira and Essex, S. (2018). The challenge of urban design in securing post-event legacies of Olympic Parks. Journal of Urban Design, 23, pp. 278-297. doi: 10.1080/13574809.2017.1395690.

Santomasso, E.A. (1980). The design of reason: architecture and planning at the 1939/40 New York World's Fair. In Harrison, H.A., ed., Dawn of a New Day: the New York World's Fair. New York: Queens Museum/New York University Press, pp. 29-41.

Schädler, S., Morio, M., Bartke, S., Rohr-Zaenker, R. and Finkel, M. (2011). Designing sustainable and economically attractive brownfield revitalization options using an integrated 
assessment model. Journal of Environmental Management, 92, pp. 827-837. doi: 10.1016/j.jenvman.2010.10.026.

Scheu, A., Preuss, H. and Könecke, T. (2019). The legacy of the Olympic Games: a review. Journal of Global Sport Management, published online. doi: 10.1080/24704067.2019.1566757

Scott, M., Lennon, M., Haase, D., Kazmierczak, A., Clabby, G. and Beatley, T. (2016). Multifunctional green infrastructure and climate change adaptation: brownfield greening as an adaptation strategy for vulnerable communities?. Planning Theory and Practice, 17, pp. 267-300. doi: 10.1080/14649357.2016.1158907.

Searle, G. (2012). The long term urban impacts of the Sydney Olympic Games. Australian Planner, 49, pp. 195-202. doi: 10.1080/07293682.2012.706960

Searle, G., Darchen, S. and Huston, S. (2014). Positive and Negative Factors for Transit Oriented Development: Case Studies from Brisbane, Melbourne and Sydney. Urban Policy and Research 32, pp. 437-457, https://doi.org/10.1080/08111146.2014.931280.

Shutkin, W.A. (2001). The Land that could be: Environmentalism and democracy in the twenty-first century. Cambridge, MA: MIT Press.

Smith, A. (2012). Events and Urban Regeneration: the strategic use of events to revitalise cities. Abingdon: Routledge.

Smith, R.M. (2017). Exploring sustainable urban development practices: The use of urban extensions in England. In Wolfe, M. ed., Urban Planning and Renewal. New York: Nova Science Publishers, pp. 85-114.

SOCOG (2000). Information Guide January 2000. Sydney: Sydney Organizing Committee for the Olympic Games.

SOPA (2018). Master Plan 2030 (2018 Review). Sydney: Sydney Olympic Park Authority.

Suh, J.-Y., Birch, G.F., Hughes, K. and Matthai, C. (2011). Spatial distribution and source of heavy metals in reclaimed lands of Homebush Bay: the venue of the 2000 Olympic Games, Sydney, New South Wales. Australian Journal of Earth Sciences, 51, pp. 53-66. doi: 10.1046/j.1400-0952.2003.01043.x.001.

Talbot, A. (2019). Talking about the 'rotten fruits' of Rio 2016: Framing mega-event legacies. International Review for the Sociology of Sport, on-line publication. doi: $10.1177 / 1012690219878842$.

Tarr, J.A. (2002). The metabolism of the industrial city: the case of Pittsburgh. Journal of Urban History, 28, pp. 511-545. doi: 10.1177/0096144202028005001 
Timms, J., 2012. The Olympics as a platform for protest: A case study of the London 2012 'ethical' Games and the Play Fair campaign for workers' rights. Leisure Studies, 31, pp.355372. doi: 10.1080/02614367.2012.667821

Tomlinson, A. (2014). Olympic legacies: Recurrent rhetoric and harsh realities.

Contemporary Social Science, 9, pp. 137-158. doi:10.1080/21582041.2014.912792

Tomlinson, A., ed. (2016). The Olympic Legacy: social scientific explorations. Abingdon: Routledge.

Weirick, J. (1999). Urban design. In Cashman, R. and Hughes, A., eds. Staging the Olympics: the event and its impact. Sydney: University of New South Wales Press, pp. 70-82. 


\begin{tabular}{|c|c|c|c|}
\hline Event Space & City and Year & Event details & Post-event use \\
\hline $\begin{array}{l}\text { Temporary } \\
\text { Solutions }\end{array}$ & $\begin{array}{l}\text { Los Angeles } \\
1932,1984, \\
2028 \\
\text { Atlanta } 1996\end{array}$ & $\begin{array}{l}\text { Use of pre-existing Los } \\
\text { Angeles Memorial } \\
\text { Coliseum and leased } \\
\text { facilities } \\
\text { Olympic Stadium, } \\
\text { temporary use of } \\
\text { University facilities }\end{array}$ & $\begin{array}{l}\text { Return to previous } \\
\text { owners and users } \\
\text { Centennial Park, partial } \\
\text { stadium demolition - } \\
\text { creation of Turner Field }\end{array}$ \\
\hline Clearance & $\begin{array}{l}\text { Seoul } 1988 \\
\text { Beijing } 2008\end{array}$ & $\begin{array}{l}\text { Seoul Sports complex and } \\
\text { Olympic Park } \\
\text { Clearance to allow creation } \\
\text { of Olympic Green, north of } \\
\text { city centre }\end{array}$ & $\begin{array}{l}\text { Sports buildings mostly } \\
\text { permanent structures, } \\
\text { museum and cultural } \\
\text { quarter } \\
\text { Retention as sporting } \\
\text { venues and cultural } \\
\text { quarter. }\end{array}$ \\
\hline $\begin{array}{l}\text { Greenfield } \\
\text { (suburban and } \\
\text { exurban sites) }\end{array}$ & $\begin{array}{l}\text { London } 1908 \\
\text { Berlin } 1936 \\
\text { Athens } 2004 \\
\text { Rio de Janeiro } \\
2016\end{array}$ & $\begin{array}{l}\text { White City stadium } \\
\text { Reichssportfeld, Maifeld } \\
\text { Olympic Park at Maroussi } \\
\text { Olympic Park at Barra da } \\
\text { Tijuca }\end{array}$ & $\begin{array}{l}\text { Stadium in use until } \\
\text { demolition in } 1984 \\
\text { Military and ceremonial; } \\
\text { later sports and } \\
\text { recreational } \\
\text { Retention as sports } \\
\text { complex } \\
\text { Redevelopment for } \\
\text { mixed legacy use }\end{array}$ \\
\hline $\begin{array}{l}\text { Remediated } \\
\text { land }\end{array}$ & $\begin{array}{l}\text { Sydney } 2000 \\
\text { London } 2012\end{array}$ & $\begin{array}{l}\text { Homebush Bay } \\
\text { Lower Lea Valley }\end{array}$ & $\begin{array}{l}\text { New suburb of Sydney; } \\
\text { mixed land-use: stadia, } \\
\text { residential, business and } \\
\text { commercial hubs } \\
\text { New London district } \\
\text { (E20): sports stadia, } \\
\text { housing, business, } \\
\text { creative industries, } \\
\text { cultural quarter }\end{array}$ \\
\hline
\end{tabular}

Table 1 Event space categories for Summer Olympic Games with representative examples 
Source: Based on Gold and Gold $(2018,355)$ 


\section{Figure Legends}

Figure 1 Pre-bid clearance and remediation of land at Homebush Bay

Source: By courtesy of R. Freestone

Figure 2 Demolition and remediation at the former State Abattoir site, Homebush Bay

Source: By courtesy of R. Freestone

Figure 3 Remedial soil cleansing works in progress, Lower Lea Valley, May 2007

Source: The Authors

Figure 4 Pudding Mill River, one of the tributary watercourses of the River Lea, Stratford, London, May 2007

Source: The Authors 